\title{
The oncomodulatory role of human cytomegalovirus in colorectal cancer: implications for clinical trials
}

\author{
Hsin-Pai Chen ${ }^{1,2,3}$ and Yu-Jiun Chan ${ }^{3,4,5}$ * \\ 1 Department of Medicine, National Yang-Ming University Hospital, Yilan, Taiwan \\ 2 School of Medicine, National Yang-Ming University, Taipei, Taiwan \\ ${ }^{3}$ Division of Infectious Diseases, Department of Medicine, Taipei Veterans General Hospital, Taipei, Taiwan \\ ${ }^{4}$ Institute of Public Health, School of Medicine, National Yang-Ming University, Taipei, Taiwan \\ ${ }^{5}$ Division of Microbiology, Department of Pathology and Laboratory Medicine, Taipei Veterans General Hospital, Taipei, Taiwan
}

\section{Edited by:}

Charles Stringfellow Cobbs, Swedish

Neuroscience Institute, USA

\section{Reviewed by:}

Sathish Kumar Mungamuri, Mount

Sinai School of Medicine, USA

Shashidhar Jatiani, Mount Sinai

Medical Center, USA

*Correspondence:

Yu-Jiun Chan, Taipei Veterans General Hospital, No. 201, Sec. 2, Shih Pai

Road, Beitou District, Taipei 11217,

Taiwan

e-mail:yjchan@vghtpe.gov.tw
Increasing evidence suggests that human cytomegalovirus (HCMV), a beta-herpes virus that chronically infects human beings, is associated with colorectal cancer (CRC). The viral nucleic acids specifically localized to the neoplastic mucosal epithelium of CRC, while tumoral presence of HCMV independently predicted a poor outcome in elderly patients. In the past decade, the concept of "oncomodulation" of HCMV in human cancers has been formulated. In CRC, changes in the tumor microenvironment are closely related to cancer behavior and prognosis, while the underlying mechanism driving these changes remains unclear. As HCMV affects multiple cellular functions, including signal pathways that regulate angiogenesis, apoptosis, cell invasiveness, and anti-cancer immunity, the virus potentially exerts oncomodulatory effects in the tumor microenvironment of CRC. Here, we summarize the current knowledge about the association between HCMV and CRC and suggest future perspectives on both research and anti-cancer therapy of CRC.

Keywords: human cytomegalovirus, colorectal cancer, oncomodulation, anti-cancer immunity, anti-cancer therapy

\section{INTRODUCTION}

Colorectal cancer (CRC) is one of the most commonly found cancers leading to significant mortality and morbidity. Despite efforts and progress made in the treatment, the survival rate is still low unless found and treated early (1). Multiple factors contribute to the outcome of CRC. The gold standard for outcome prediction is based on the tumor-node-metastasis classification of the Union for International Cancer Control (TNM-UICC). However, since the pathogenesis of CRC involves multiple and heterogeneous pathways, an observation based merely on anatomy and histology may sometimes be misleading. Patients of the same stage frequently have dramatically different outcomes. Such dis-concordance may result from changes in tumor microenvironments that have been shown to be closely associated with prognosis (2). Nevertheless, the underlying mechanisms driving these microenvironmental changes in cancer behavior and subsequent local anti-cancer immunity in the tumor microenvironment remain obscure.

Virus as an oncogenic agent has long been recognized, for example, human hepatitis $B$ and $C$ viruses to hepatoma and human papilloma virus to cervical cancer. A certain herpes group virus, such as Epstein-Barr (EB) virus, has been shown to relate to nasopharyngeal carcinoma and Burkitt's lymphoma. However, human cytomegalovirus (HCMV), a beta-herpesvirus that contains many potential viral onco-proteins, has not been categorized as an oncogenic virus till now. This virus infects $60-90 \%$ of the general population and is regarded as an oncomodulatory virus because of its effects on cell-cycle progression, mutagenesis, angiogenesis, and immune evasion (3-5). It was a long debate whether HCMV may act as an oncomodulatory virus. First, whether HCMV can be found in various tumorous tissues is skeptical, although its gene components and gene products had been detected in a number of human cancers (6-10). It is much clearer now HCMV can be detected in a certain tumors, including CRC. In CRC, several studies have identified HCMV in the tumor tissues (11-13). We previously reported that $\sim 40 \%$ of the CRC specimens were positive for HCMV (13). Later, we found tumoral presence of HCMV is associated with an unfavorable outcome in elderly CRC patients and predicts a shorter disease-free survival, independent of that expected by the TNM stage (14). Such findings imply that HCMV may affect the tumor microenvironment of CRC via a certain immune pathway. Theoretically, upon infection, HCMV is able to up-regulate different host cellular signal pathways, growth factors, and cytokines, resulting in enhanced cell survival, proliferation, and angiogenesis (15). As such, HCMV appears to regulate the malignant behavior of tumor cells, implying an oncomodulatory role for the virus.

\section{THE ASSOCIATION BETWEEN HCMV AND OUTCOME OF CRC: INCREASING EVIDENCE HCMV PREFERENTIALLY INFECTS THE TUMORAL EPITHELIUM OF COLORECTAL CANCER}

Using paired tumor and adjacent non-neoplastic CRC specimens, we recently reported that HCMV preferentially infects the neoplastic epithelium of CRC. HCMV DNA was detected by PCR in $42.3 \%(69 / 163)$ of the tumor specimens, while only $5.6 \%$ $(14 / 163)$ samples of adjacent non-neoplastic tissue were positive for HCMV $(p<0.0001)$ (13). Significantly higher viral copies 
were found in the tumor specimens than the adjacent nonneoplastic tissue specimens. By in situ hybridization, the nucleic acids of HCMV specifically localized to the cytoplasm of neoplastic epithelium, but not the submucosa, stroma, or inflammatory infiltrations surrounding the tumor epithelium. These results indicate that HCMV preferentially infects, or reactivates in, the tumor epithelium of CRC, and is concordant with several previous studies that reported positive detection of HCMV in CRC $(11,12)$.

However, detection of HCMV in CRC had been associated with controversial results. (16-19). Negative detection of HCMV may be attributed to several factors. Among the various techniques used, a PCR-based detection of viral nucleic acids is both rapid and sensitive, and is the most widely applied on detecting HCMV in clinical samples. However, the selection of genes, the primer design, and the quality and type of samples can all have substantial influence on the result $(20,21)$. PCR detection of viral nucleic acids may fail if the tissue has been processed extensively by formalin, which causes fragmentation of DNA $(22,23)$. Frozen samples, on the other hand, are more suitable for DNA preservation and subsequent PCR detection (24, 25). Moreover, HCMV may only infect malignant cells that are at specific stages of cell differentiation and maintains a "low-grade infection" status in tumor $(20,26$, 27 ). If the sample volume is too small, a false negative detection is expected.

\section{TUMORAL PRESENCE OF HUMAN CYTOMEGALOVIRUS IS ASSOCIATED WITH SHORTER DISEASE-FREE SURVIVAL IN ELDERLY PATIENTS WITH CRC}

The relationship between HCMV and the outcome of CRC was demonstrated in our recent study in which an association between HCMV and a poor survival outcome in the elderly patients was found. Significant interaction is seen between HCMV and the elderly. In the elderly, HCMV tends to get reactivated more frequently because of the age-related decline of cell-mediated immunity $(28,29)$. On the other hand, chronic cytomegaloviral infection is detrimental to the older population, associated with increased mortality in elderly (30). The underlying mechanism may be that chronic HCMV infection results in phenotypic and functional alterations of adaptive immunity in the elderly, a status referred to as "immunosenescence" (31-34).

We recently investigated the relationship between tumoral presence of HCMV and the outcome of elderly patients with CRC. In the 81 patients who underwent curative surgery, the 39 patients with HCMV-positive tumors had a lower disease-free survival rate compared with those without HCMV in tumor $(P=0.024)$. For patients with stage II or III diseases, tumoral HCMV status correlated with disease-free survival more closely than the tumornode-metastasis (TNM) staging method. Using a multivariate Cox proportional-hazards model, tumoral infection by HCMV independently predicted disease recurrence in 5 years (hazard ratio, 4.42; 95\% confidence interval, $1.54-12.69 ; P=0.006)$. It is surprising that within specific tumor stages, tumoral presence of HCMV correlated with the outcome more closely than the traditional histopathological staging method. Such finding argues for an important role that the virus may play in the tumor microenvironment of CRC.

\section{PERSPECTIVES OF THE ONCOMODULATORY ROLE OF HCMV IN CRC HCMV AND ANTI-CANCER IMMUNITY IN THE CANCER MICROENVIRONMENT \\ HCMV and tumor-associated macrophages}

Tumor-associated macrophages (TAMs) are derived from blood monocytes that are recruited to the tumor. Macrophages can be activated to either M1, the anti-tumor, or M2, the pro-tumor, polarization states depending on the microenvironment stimuli. The M1 macrophages are part of the T-helper $\left(\mathrm{T}_{\mathrm{H}}\right) 1$ response and are potent effectors against intracellular pathogens and tumor cells. On the other hand, the M2 macrophages are involved in promoting angiogenesis, tissue remodeling and repair, and are part of the $\mathrm{T}_{\mathrm{H}} 2$ response. TAMs with $\mathrm{M} 2$ polarization are a major tumorinfiltrating cell population (35). High TAM density in tumors is now recognized as a poor prognostic sign in CRC (36).

When directly infecting the monocyte, HCMV renders monocyte differentiation toward an M1 macrophage (37). However, according to a recent study of human glioma, HCMV encodes an interleukin (IL)-10 homolog, the cmvIL-10, which binds to the human IL-10 receptor. Binding of cmvIL-10 renders the monocytes in glioma to assume an M2 phenotype and turns the anti-cancer immunity toward the immunosuppressive and tumor-propagating phenotype (38). It would be valuable to study whether the presence of HCMV in CRC was also associated with a tumor-propagating phenotype of TAM.

\section{HCMV and tumor-infiltrating T cells}

Using immunohistochemical staining, quantitative PCR, and large-scale flowcytometry, recent studies have demonstrated the critical role of localized adaptive immune reaction in the prognosis of cancer behavior and prognosis $(39,40)$. The T cell-mediated immunity within the tumor tissue predicts the outcome of CRC independently to that of the traditional TNM-UICC stage of the tumor (40). In CRC, a shift from $\mathrm{T}_{\mathrm{H}} 1$ to $\mathrm{T}_{\mathrm{H}} 2$ response in $\mathrm{CD}^{+}$lymphocytes was noted (41). Such shift from $\mathrm{T}_{\mathrm{H}} 1$ to $\mathrm{T}_{\mathrm{H}} 2$ polarization of $\mathrm{CD}^{+}$lymphocytes renders the tumor-specific cytotoxic $\mathrm{CD}^{+}$inactive. CRC also shows high levels of $\mathrm{MHC}$ class-I alteration, with loss or downregulation of class-I MHC molecules resulting from alteration in processing or presentation $(42,43)$. The overall effect is immunosuppression and tolerance of tumor growth. The underlying mechanism driving the alteration in $\mathrm{T}$ cell-mediated immunity within the tumor microenvironment remains obscure.

Interestingly, HCMV infection results in an immunosuppressive status resembling to that found in CRC. To escape the surveillance of cytotoxic T cells, HCMV encodes several viral genes (US2, $3,6,11$ ) that downregulate the level of MHC class-I molecules on the surface of infected cells (44). In organ transplant recipients, who suffer from active HCMV diseases, the transcription of IL-10 and transforming growth factor (TGF) $-\beta$ is significantly increased, while the expression of interferon (IFN) $-\gamma$ is reduced, suggesting a shift from pro-inflammatory $\mathrm{T}_{\mathrm{H}} 1$ to the immune-tolerogenic $\mathrm{T}_{\mathrm{H}} 2$ response and resemble that found in CRC $(45,46)$.

In a small number of CRC samples, we analyzed the transcription levels of signal pathways of the major $\mathrm{T}_{\mathrm{H}}$ subsets, including $\mathrm{T}_{\mathrm{H}} 1, \mathrm{~T}_{\mathrm{H}} 2$, regulatory $\mathrm{T}\left(\mathrm{T}_{\mathrm{reg}}\right)$, and a newly defined subset, 
the $\mathrm{T}_{\mathrm{H}} 17$ that has recently been correlated to a poorer outcome of CRC $(47,48)$. We found a higher transcription level of IL 17 - the signature cytokine of $\mathrm{T}_{\mathrm{H}} 17$ cells - in HCMVpositive tumors (14). Based on this finding, we speculate that HCMV may be one of the underlying forces that drive the alteration of anti-tumor immunity in the tumor microenvironment of CRC.

\section{HCMV INFECTION AND THE CELLULAR SIGNAL PATHWAYS THAT CORRELATE WITH CANCER PROGRESSION HCMV and cyclooxygenase-2 pathway}

Cyclooxygenase (COX) is a key enzyme in the prostaglandin biosynthetic pathway. COX-2, the inducible isoform of COX, has received considerable attention due to its role in human cancers. Activation of the COX-2 activity in tumor tissue leads to promotion of angiogenesis, resistance to apoptosis, immune modulation, and increase of cell invasiveness and metastasis (49-51). In CRC, overexpression of COX-2 in CRC tissues correlates with poor prognosis (52), while inhibition of the COX activity by non-steroidal anti-inflammatory drugs (NSAIDs) results in protective effects for CRC (53-55).

Human cytomegalovirus is also an inducer of COX-2, which plays an important role in viral replication (56). In permissive cells, inhibition of COX-2 results in marked reduction of HCMV (57). It was previously reported that COX-2 expression in CRC was concordant with areas of HCMV IE1-72 and pp65 immunoreactivity (12).

\section{HCMV may promote angiogenesis in cancer}

Induction of angiogenesis is one of the key factors that promote tumor growth and cancer survival. The microvascular density of a tumor has prognostic significance and predicts survival in patients with CRC (58).

Mounting evidence suggests that HMCV may promote angiogenesis. HCMV-infected cells directly induce angiogenesis by secreting VEGF and other angiogenic factors (59), promoting vascular tube formation (60). The HCMV gene US28 was shown to be involved in the HCMV-induced angiogenic phenotype (61). Analysis of clinical glioblastoma specimens revealed that US28 co-localized with several factors of angiogenesis (62).

\section{HCMV promotes cell proliferation and inhibits apoptosis}

Human cytomegalovirus is found to promote cell proliferation in cancer. In a mouse model of glioblastoma, cytomegalovirus infection enabled the malignant cells to survive and multiply, leading to shorter survival (63). HCMV also encodes multiple antiapoptotic proteins, including the viral mitochondrion-localized inhibitor of apoptosis (vMIA) or UL37 exon 1, UL36, and UL38 proteins, to prevent host cells from programed death and to support viral survival $(64,65)$.

\section{HCMV infection alters the expression of matrix metalloproteinases that are important in cancer metastasis}

Matrix metalloproteinases (MMPs) are zinc-dependent endopeptidases. These enzymes are capable of degrading extracellular matrix proteins and play a major role on cell behaviors such as cell proliferation, migration, differentiation, angiogenesis, apoptosis, and host defense (66). The expression levels of some MMPs are correlated with stage of disease and/or prognosis (67).
Table 1 | Anti-viral agents for human cytomegalovirus.

\begin{tabular}{lll}
\hline Drug name & $\begin{array}{l}\text { Pharmaceutical } \\
\text { preparation }\end{array}$ & Major adverse effects \\
\hline Ganciclovir & $\begin{array}{l}\text { Mainly } \\
\text { intravenous }\end{array}$ & $\begin{array}{l}\text { Cytopenia, teratogenicity/ } \\
\text { carcinogenicity and aspermia } \\
\text { in animals }\end{array}$ \\
$\begin{array}{l}\text { Valganciclovir } \\
\text { Cidofovir }\end{array}$ & $\begin{array}{l}\text { Oral } \\
\text { Intravenous }\end{array}$ & $\begin{array}{l}\text { Same as ganciclovir } \\
\text { Nephrotoxicity }\end{array}$ \\
\hline
\end{tabular}

Human cytomegalovirus infection is associated with a significant alteration of MMPs in mRNA, protein, and functional levels (68). Among them, MMP-9 negativity is associated with poor survival, while its positivity predicts a favorable outcome of CRC (69). A reduction in MMP-9 mRNA, protein, and activity levels but increased tissue inhibitor of matrix proteinases (TIMP)-1 mRNA and protein levels was found after HCMV infection (68). MMP-9 mRNA expression was affected by an immediate-early or early viral gene product, whereas TIMP-1 mRNA expression was affected by late viral gene products. Furthermore, a higher mRNA level of MMP-1, a marker for hematogenous metastasis of CRC (70), had been demonstrated in HCMV-positive clinical specimens (71).

\section{CAN ANTI-HCMV TREATMENT CHANGE THE OUTCOME OF CRC?}

Traditional treatments for CRC include surgery, radiotherapy, and chemotherapy. Introducing an anti-viral agent or anti-viral immunotherapy for CRC has never been tested. Based on aforementioned evidence for HCMV as an oncomodulatory agent, it is justifiable to test the hypothesis that treating elderly patients whose tumor is positive for HCMV may improve the outcome.

For HCMV infection, there are currently four anti-viral drugs licensed for treatment: ganciclovir, valganciclovir, cidofovir, and foscarnet (Table 1). Ganciclovir is a synthetic analog of deoxyguanosine. It is the first anti-viral agent approved for treatment of cytomegaloviral disease and remains the first-line treatment (72). Valganciclovir is the L-valyl ester prodrug of ganciclovir, with excellent bioavailability equivalent to that of intravenous ganciclovir. Both drugs have the major adverse effect of cytopenia. Cidofovir is a broad-spectrum anti-viral agent with potency against many DNA viruses including smallpox virus (73). However, severe renal toxicity limits its use as an anti-viral agent. Foscarnet is usually considered as second-line therapy for patients who are failing ganciclovir therapy due to major side effects or viral resistance (72).

Supportive data from glioblastoma trial may render this notion promising. In a randomized double-blind trial, patients with HCMV-positive glioblastoma were treated with valganciclovir as an add-on therapy. The results demonstrated beneficiary prognosis for this subset of patients (74). By the same token, a subset (15-40\%) of HCMV-positive CRC patients may gain benefits from anti-viral treatment. A prospective randomized controlled trial is critical to confirm the hypothesis.

\section{CONCLUSION}

Increasing clinical and experimental findings suggest that HCMV may be an oncomodulatory virus for human CRC. However, 
the definite role of HCMV needs to be further investigated in a systematic manner to obtain a comprehensive and holistic understanding. From bench to bed, the clinical relevance of the oncomodulating effects should be testified through a multifaceted approach. Moreover, a randomized controlled trial is needed to clarify whether anti-viral therapy is beneficial to CRC patients with HCMV detected in the tumor. The results of such studies may provide a new insight into the pathogenesis of at least a subset of CRC and hopefully bring about new strategies for cancer therapy.

\section{REFERENCES}

1. O'Connell JB, Maggard MA, Ko CY. Colon cancer survival rates with the new American joint committee on cancer sixth edition staging. J Natl Cancer Inst (2004) 96:1420-5. doi:10.1093/jnci/djh275

2. Peddareddigari VG, Wang D, Dubois RN. The tumor microenvironment in colorectal carcinogenesis. Cancer Microenviron (2010) 3:149-66. doi:10.1007/ s12307-010-0038-3

3. Castillo JP, Kowalik TF. Human cytomegalovirus immediate early proteins and cell growth control. Gene (2002) 290:19-34. doi:10.1016/S0378-1119(02) 00566-8

4. Cinatl J Jr, Cinatl J, Vogel JU, Rabenau H, Kornhuber B, Doerr HW. Modulatory effects of human cytomegalovirus infection on malignant properties of cancer cells. Intervirology (1996) 39:259-69.

5. Powers C, DeFilippis V, Malouli D, Früh K. Cytomegalovirus immune evasion. Curr Top Microbiol Immunol (2008) 325:333-59. doi:10.1007/978-3-54077349-8_19

6. Cobbs CS, Harkins L, Samanta M, Gillespie GY, Bharara S, King PH, et al. Human cytomegalovirus infection and expression in human malignant glioma. Cancer Res (2002) 62:3347-50. doi:10.3892/ijo.21.1.31

7. Giraldo G, Beth E, Huang ES. Kaposi's sarcoma and its relationship to cytomegalovirus (CMNV). III. CMV DNA and CMV early antigens in Kaposi's sarcoma. Int J Cancer (1980) 26:23-9. doi:10.1002/ijc.2910260105

8. Huang G, Yan Q, Wang Z, Chen X, Zhang X, Guo Y, et al. Human cytomegalovirus in neoplastic cells of Epstein-Barr virus negative Hodgkin's disease. Int J Oncol (2002) 21:31-6.

9. Pacsa AS, Kummerlander L, Pejtsik B, Pali K. Herpesvirus antibodies and antigens in patients with cervical anaplasia and in controls. J Natl Cancer Inst (1975) 55:775-81.

10. Sanford EJ, Geder L, Laychock A, Rohner TJ Jr, Rapp F. Evidence for the association of cytomegalovirus with carcinoma of the prostate. J Urol (1977) 118:789-92.

11. Huang ES, Roche JK. Cytomegalovirus D.N.A. and adenocarcinoma of the colon: evidence for latent viral infection. Lancet (1978) 1:957-60. doi:10.1016/S01406736(78)90248-9

12. Harkins L, Volk AL, Samanta M, Mikolaenko I, Britt WJ, Bland KI, et al. Specific localisation of human cytomegalovirus nucleic acids and proteins in human colorectal cancer. Lancet (2002) 360:1557-63. doi:10.1016/S0140-6736(02) 11524-8

13. Chen HP, Jiang JK, Chen CY, Chou TY, Chen YC, Chang YT, et al. Human cytomegalovirus preferentially infects the neoplastic epithelium of colorectal cancer: a quantitative and histological analysis. J Clin Virol (2012) 54:240-4. doi:10.1016/j.jcv.2012.04.007

14. Chen HP, Jiang JK, Lai PY, Chen CY, Chou TY, Chen YC, et al. Tumoral presence of human cytomegalovirus is associated with shorter disease-free survival in elderly patients with colorectal cancer and higher levels of intratumoral interleukin-17. Clin Microbiol Infect (2014) 20:664-71. doi:10.1111/1469-0691. 12412

15. Cinatl J Jr, Vogel JU, Kotchetkov R, Wilhelm Doerr H. Oncomodulatory signals by regulatory proteins encoded by human cytomegalovirus: a novel role for viral infection in tumor progression. FEMS Microbiol Rev (2004) 28:59-77. doi:10.1016/j.femsre.2003.07.005

16. Akintola-Ogunremi O, Luo Q, He TC, Wang HL. Is cytomegalovirus associated with human colorectal tumorigenesis? Am J Clin Pathol (2005) 123:244-9. doi:10.1309/9QVRHDJUK6H2TURB

17. Boguszaková L, Hirsch I, Brichácek B, Faltýn J, Fric P, Dvoráková $H$, et al. Absence of cytomegalovirus, Epstein-Barr virus, and papillomavirus DNA from adenoma and adenocarcinoma of the colon. Acta Virol (1988) 32: 303-8.
18. Brichacek B, Hirsch I, Zavadova H, Prochazka M, Faltyn J, Vonka V. Absence of cytomegalovirus DNA from adenocarcinoma of the colon. Intervirology (1980) 14:223-7. doi:10.1159/000149187

19. Hart H, Neill WA, Norval M. Lack of association of cytomegalovirus with adenocarcinoma of the colon. Gut (1982) 23:21-30. doi:10.1136/gut.23.1.21

20. Ranganathan P, Clark PA, Kuo JS, Salamat MS, Kalejta RF. Significant association of multiple human cytomegalovirus genomic loci with glioblastoma multiforme samples. J Virol (2012) 86:854-64. doi:10.1128/JVI.06097-11

21. Chen HP, Lin JC, Yang SP, Lan YC, Weng WS, Tsai CH, et al. The type-2 variant of human cytomegalovirus glycoprotein $\mathrm{n}$ (gn-2) is not the rarest in the Chinese population of Taiwan: influence of primer design. J Virol Methods (2008) 151:161-4. doi:10.1016/j.jviromet.2008.03.018

22. Koshiba M, Ogawa K, Hamazaki S, Sugiyama T, Ogawa O, Kitajima T. The effect of formalin fixation on DNA and the extraction of high-molecular-weight DNA from fixed and embedded tissues. Pathol Res Pract (1993) 189:66-72. doi:10.1016/S0344-0338(11)80118-4

23. Rogers BB, Alpert LC, Hine EA, Buffone GJ. Analysis of DNA in fresh and fixed tissue by the polymerase chain reaction. Am J Pathol (1990) 136:541-8.

24. Ferrer I, Armstrong J, Capellari S, Parchi P, Arzberger T, Bell J, et al. Effects of formalin fixation, paraffin embedding, and time of storage on DNA preservation in brain tissue: a Brainnet Europe study. Brain Pathol (2007) 17:297-303. doi:10.1111/j.1750-3639.2007.00073.x

25. Rollo F, Ermini L, Luciani S, Marota I, Olivieri C. Studies on the preservation of the intestinal microbiota's DNA in human mummies from cold environments. Med Secoli (2006) 18:725-40.

26. Esclatine A, Bellon A, Michelson S, Servin AL, Quero AM, Geniteau-Legendre M. Differentiation-dependent redistribution of heparan sulfate in epithelial intestinal caco-2 cells leads to basolateral entry of cytomegalovirus. Virology (2001) 289:23-33. doi:10.1006/viro.2001.1122

27. Jarvis MA, Wang CE, Meyers HL, Smith PP, Corless CL, Henderson GJ, et al. Human cytomegalovirus infection of caco-2 cells occurs at the basolateral membrane and is differentiation state dependent. J Virol (1999) 73:4552-60.

28. McVoy MA, Adler SP. Immunologic evidence for frequent age-related cytomegalovirus reactivation in seropositive immunocompetent individuals. J Infect Dis (1989) 160:1-10. doi:10.1093/infdis/160.1.1

29. Stowe RP, Kozlova EV, Yetman DL, Walling DM, Goodwin JS, Glaser R. Chronic herpesvirus reactivation occurs in aging. Exp Gerontol (2007) 42:563-70. doi:10.1016/j.exger.2007.01.005

30. Savva GM, Pachnio A, Kaul B, Morgan K, Huppert FA, Brayne C, et al. Cytomegalovirus infection is associated with increased mortality in the older population. Aging Cell (2013) 12:381-7. doi:10.1111/acel.12059

31. Vasto S, Colonna-Romano G, Larbi A, Wikby A, Caruso C, Pawelec G. Role of persistent $\mathrm{CMV}$ infection in configuring t cell immunity in the elderly. Immun Ageing (2007) 4:2. doi:10.1186/1742-4933-4-2

32. Hadrup SR, Strindhall J, Køllgaard T, Seremet T, Johansson B, Pawelec G, et al. Longitudinal studies of clonally expanded $\mathrm{cd} 8 \mathrm{t}$ cells reveal a repertoire shrinkage predicting mortality and an increased number of dysfunctional cytomegalovirus-specific t cells in the very elderly. J Immunol (2006) 176:2645-53. doi:10.4049/jimmunol.176.4.2645

33. Koch S, Solana R, Dela Rosa O, Pawelec G. Human cytomegalovirus infection and t cell immunosenescence: a mini review. Mech Ageing Dev (2006) 127:538-43. doi:10.1016/j.mad.2006.01.011

34. Pawelec G, Koch S, Griesemann H, Rehbein A, Hahnel K, Gouttefangeas C. Immunosenescence, suppression and tumour progression. Cancer Immunol Immunother (2006) 55:981-6. doi:10.1007/s00262-005-0109-3

35. Sica A, Schioppa T, Mantovani A, Allavena P. Tumour-associated macrophages are a distinct $\mathrm{m} 2$ polarised population promoting tumour progression: Potential targets of anti-cancer therapy. Eur J Cancer (2006) 42:717-27. doi:10.1016/ j.ejca.2006.01.003

36. Bacman D, Merkel S, Croner R, Papadopoulos T, Brueckl W, Dimmler A. Tgfbeta receptor 2 downregulation in tumour-associated stroma worsens prognosis and high-grade tumours show more tumour-associated macrophages and lower tgf-betal expression in colon carcinoma: a retrospective study. BMC Cancer (2007) 7:156. doi:10.1186/1471-2407-7-156

37. Chan G, Bivins-Smith ER, Smith MS, Smith PM, Yurochko AD. Transcriptome analysis reveals human cytomegalovirus reprograms monocyte differentiation toward an ml macrophage. J Immunol (2008) 181:698-711. doi:10.4049/ jimmunol.181.1.698

38. Dziurzynski K, Wei J, Qiao W, Hatiboglu MA, Kong LY, Wu A, et al. Gliomaassociated cytomegalovirus mediates subversion of the monocyte lineage to a 
tumor propagating phenotype. Clin Cancer Res (2011) 17:4642-9. doi:10.1158/ 1078-0432.CCR-11-0414

39. Pagès F, Berger A, Camus M, Sanchez-Cabo F, Costes A, Molidor R, et al. Effector memory t cells, early metastasis, and survival in colorectal cancer. $N$ Engl J Med (2005) 353:2654-66. doi:10.1056/NEJMoa051424

40. Chan G, Bivins-Smith ER, Smith MS, Yurochko AD. Transcriptome analysis of nf-kappab- and phosphatidylinositol 3-kinase-regulated genes in human cytomegalovirus-infected monocytes. J Virol (2008) 82:1040-6. doi:10.1128/ JVI.00864-07

41. Evans C, Dalgleish AG, Kumar D. Review article: immune suppression and colorectal cancer. Aliment Pharmacol Ther (2006) 24:1163-77. doi:10.1111/j.13652036.2006.03075.x

42. Cabrera T, Collado A, Fernandez MA, Ferron A, Sancho J, Ruiz-Cabello F, et al. High frequency of altered HLA class I phenotypes in invasive colorectal carcinomas. Tissue Antigens (1998) 52:114-23. doi:10.1111/j.1399-0039.1998. tb02274.x

43. Menon AG, Morreau H, Tollenaar RA, Alphenaar E, Van Puijenbroek M, Putter $\mathrm{H}$, et al. Down-regulation of HLA-A expression correlates with a better prognosis in colorectal cancer patients. Lab Invest (2002) 82:1725-33. doi:10.1097/01.LAB.0000043124.75633.ED

44. Mocarski ES Jr. Immunomodulation by cytomegaloviruses: manipulative strategies beyond evasion. Trends Microbiol (2002) 10:332-9. doi:10.1016/S0966842X(02)02393-4

45. Nordøy I, Müller F, Nordal KP, Rollag H, Lien E, Aukrust P, et al. The role of the tumor necrosis factor system and interleukin-10 during cytomegalovirus infection in renal transplant recipients. J Infect Dis (2000) 181:51-7. doi:10.1086/ 315184

46. Zhang Y, Wang YL, Liu YW, Li Q, Yuan YH, Niu WY, et al. Change of peripheral blood mononuclear cells IFN-gamma, IL-10, and TGF-beta1 MRNA expression levels with active human cytomegalovirus infection in orthotopic liver transplantation. Transplant Proc (2009) 41:1767-9. doi:10.1016/j.transproceed.2009. 03.064

47. Rahbar A, Orrego A, Peredo I, Dzabic M, Wolmer-Solberg N, Strååt K, et al. Human cytomegalovirus infection levels in glioblastoma multiforme are of prognostic value for survival. J Clin Virol (2013) 57:36-42. doi:10.1016/j.jcv. 2012.12.018

48. Soderberg-Naucler C, Rahbar A, Stragliotto G. Survival in patients with glioblastoma receiving valganciclovir. N Engl J Med (2013) 369:985-6. doi:10.1056/ NEJMc1302145

49. Brown JR, DuBois RN. Cox-2: a molecular target for colorectal cancer prevention. J Clin Oncol (2005) 23:2840-55. doi:10.1200/JCO.2005.09.051

50. Sinicrope FA, Gill S. Role of cyclooxygenase-2 in colorectal cancer. Cancer Metastasis Rev (2004) 23:63-75. doi:10.1023/A:1025863029529

51. Greenhough A, Smartt HJ, Moore AE, Roberts HR, Williams AC, Paraskeva $\mathrm{C}$, et al. The cox-2/pge2 pathway: key roles in the hallmarks of cancer and adaptation to the tumour microenvironment. Carcinogenesis (2009) 30:377-86. doi:10.1093/carcin/bgp014

52. Zhang H, Sun XF. Overexpression of cyclooxygenase-2 correlates with advanced stages of colorectal cancer. Am J Gastroenterol (2002) 97:1037-41. doi:10.1111/ j.1572-0241.2002.05625.x

53. Thun MJ, Namboodiri MM, Heath CW Jr. Aspirin use and reduced risk of fatal colon cancer. N Engl J Med (1991) 325:1593-6. doi:10.1056/ NEJM199112053252301

54. Baron JA, Cole BF, Sandler RS, Haile RW, Ahnen D, Bresalier R, et al. A randomized trial of aspirin to prevent colorectal adenomas. N Engl J Med (2003) 348:891-9. doi:10.1056/NEJMoa021735

55. Phillips RK, Wallace MH, Lynch PM, Hawk E, Gordon GB, Saunders BP, et al. A randomised, double blind, placebo controlled study of celecoxib, a selective cyclooxygenase 2 inhibitor, on duodenal polyposis in familial adenomatous polyposis. Gut (2002) 50:857-60. doi:10.1136/gut.50.6.857

56. Yi HA, Kim MS, Jang SY, Lee YM, Ahn JH, Lee CH. Cellular signals involved in cyclooxygenase-2 expression induced by human cytomegalovirus. Virus Res (2009) 146:89-96. doi:10.1016/j.virusres.2009.09.004

57. Zhu H, Cong JP, Yu D, Bresnahan WA, Shenk TE. Inhibition of cyclooxygenase 2 blocks human cytomegalovirus replication. Proc Natl Acad Sci U S A. (2002) 99:3932-7. doi:10.1073/pnas.052713799

58. Choi HJ, Hyun MS, Jung GJ, Kim SS, Hong SH. Tumor angiogenesis as a prognostic predictor in colorectal carcinoma with special reference to mode of metastasis and recurrence. Oncology (1998) 55:575-81. doi:10.1159/000011915
59. Caposio P, Orloff SL, Streblow DN. The role of cytomegalovirus in angiogenesis. Virus Res (2011) 157:204-11. doi:10.1016/j.virusres.2010.09.011

60. Botto S, Streblow DN, DeFilippis V, White L, Kreklywich CN, Smith PP, et al. IL6 in human cytomegalovirus secretome promotes angiogenesis and survival of endothelial cells through the stimulation of survivin. Blood (2011) 117:352-61. doi:10.1182/blood-2010-06-291245

61. Maussang D, Verzijl D, van Walsum M, Leurs R, Holl J, Pleskoff O, et al. Human cytomegalovirus-encoded chemokine receptor us28 promotes tumorigenesis. Proc Natl Acad Sci U S A (2006) 103:13068-73. doi:10.1073/pnas.0604433103

62. Soroceanu L, Matlaf L, Bezrookove V, Harkins L, Martinez R, Greene M, et al. Human cytomegalovirus us 28 found in glioblastoma promotes an invasive and angiogenic phenotype. Cancer Res (2011) 71:6643-53. doi:10.1158/0008-5472. CAN-11-0744

63. Price RL, Bingmer K, Harkins L, Iwenofu OH, Kwon $\mathrm{CH}$, Cook C, et al. Cytomegalovirus infection leads to pleomorphic rhabdomyosarcomas in trp53土 mice. Cancer Res (2012) 72:5669-74. doi:10.1158/0008-5472.CAN-122425

64. Goldmacher VS, Bartle LM, Skaletskaya A, Dionne CA, Kedersha NL, Vater CA, et al. A cytomegalovirus-encoded mitochondria-localized inhibitor of apoptosis structurally unrelated to bcl-2. Proc Natl Acad Sci U S A (1999) 96:12536-41. doi:10.1073/pnas.96.22.12536

65. Skaletskaya A, Bartle LM, Chittenden T, McCormick AL, Mocarski ES, Goldmacher VS. A cytomegalovirus-encoded inhibitor of apoptosis that suppresses caspase-8 activation. Proc Natl Acad Sci U S A (2001) 98:7829-34. doi:10.1073/ pnas. 141108798

66. Van Lint P, Libert C. Chemokine and cytokine processing by matrix metalloproteinases and its effect on leukocyte migration and inflammation. J Leukoc Biol (2007) 82:1375-81. doi:10.1189/jlb.0607338

67. Zucker S, Vacirca J. Role of matrix metalloproteinases (MMPs) in colorectal cancer. Cancer Metastasis Rev (2004) 23:101-17. doi:10.1023/A: 1025867130437

68. Straat K, de Klark R, Gredmark-Russ S, Eriksson P, Soderberg-Naucler C. Infection with human cytomegalovirus alters the $\mathrm{mmp}-9 /$ timp-1 balance in human macrophages. J Virol (2009) 83:830-5. doi:10.1128/JVI.01363-08

69. Koskensalo S, Hagström J, Linder N, Lundin M, Sorsa T, Louhimo J, et al. Lack of mmp-9 expression is a marker for poor prognosis in dukes' b colorectal cancer. BMC Clin Pathol (2012) 12:24. doi:10.1186/1472-6890-12-24

70. O’Connell JB, Maggard MA, Liu JH, Etzioni DA, Ko CY. A report card on outcomes for surgically treated gastrointestinal cancers: are we improving? J Surg Res (2004) 121:214-21. doi:10.1016/j.jss.2004.04.002

71. Botero JE, Contreras A, Parra B. Effects of cytomegalovirus infection on the mRNA expression of collagens and matrix metalloproteinases in gingival fibroblasts. J Periodontal Res (2008) 43:649-57. doi:10.1111/j.1600-0765.2007.01053.x

72. Razonable RR, Emery VC. Management of CMV infection and disease in transplant patients. 27-29 February 2004. Herpes (2004) 11:77-86.

73. Biron KK. Antiviral drugs for cytomegalovirus diseases. Antiviral Res (2006) 71:154-63. doi:10.1016/j.antiviral.2006.05.002

74. Stragliotto G, Rahbar A, Solberg NW, Lilja A, Taher C, Orrego A, et al. Effects of valganciclovir as an add-on therapy in patients with cytomegalovirus-positive glioblastoma: a randomized, double-blind, hypothesis-generating study. Int J Cancer (2013) 133:1204-13. doi:10.1002/ijc.28111

Conflict of Interest Statement: The authors declare that the research was conducted in the absence of any commercial or financial relationships that could be construed as a potential conflict of interest.

Received: 31 July 2014; accepted: 21 October 2014; published online: 17 November 2014.

Citation: Chen H-P and Chan Y-J (2014) The oncomodulatory role of human cytomegalovirus in colorectal cancer: implications for clinical trials. Front. Oncol. 4:314. doi: $10.3389 /$ fonc.2014.00314

This article was submitted to Molecular and Cellular Oncology, a section of the journal Frontiers in Oncology.

Copyright $\odot 2014$ Chen and Chan. This is an open-access article distributed under the terms of the Creative Commons Attribution License (CC BY). The use, distribution or reproduction in other forums is permitted, provided the original author(s) or licensor are credited and that the original publication in this journal is cited, in accordance with accepted academic practice. No use, distribution or reproduction is permitted which does not comply with these terms. 